\title{
Numerical study of effects of mountains and lakes on a squall line in northern Jiangsu Province
}

\author{
Bin $\mathrm{Li}^{1}$ (i) $\cdot$ Liguang $\mathrm{Wu}^{2}$
}

Received: 7 March 2019 / Accepted: 17 December 2019 / Published online: 20 January 2020

(c) The Author(s) 2020

\begin{abstract}
Observational studies indicate that northern Jiangsu Province is the most active area for the occurrence of squall lines in east China. While the roles of the large-scale atmospheric environment have been investigated, the effects of the terrain and lakes on the squall line in northern Jiangsu Province have not been well understood. In this study, the squall line occurring on 14 June 2009 is simulated to investigate the influences of the terrain and lakes. The squall line occurred under the influence of a short westerly trough at $500 \mathrm{hPa}$, one of the typical synoptic-scale patterns favorable for the development of squall lines in east China. Using the grid spacings of $3 \mathrm{~km}, 1 \mathrm{~km}$ and $333 \mathrm{~m}$, the Weather Research and Forecast model (WRF) reasonably well simulates the evolution of the squall line and the extreme rainfall. Sensitivity experiments are conducted to examine the effects of Mountain Meng, Hongze Lake and Gaoyou Lake. It is found that the valley wind associated with Mountain Meng plays an important role in the early development of the squall line by enhancing the vertical wind shear at the low levels. The presence of the lakes leads to a relatively cold area, resulting in a temperature gradient toward the southeast at the low levels. The horizontal temperature gradient enhances the low-level vertical wind shear and promotes the development of the squall line.
\end{abstract}

\section{Introduction}

Squall lines are associated with strong surface winds, heavy rainfall, hail, and even tornadoes, usually causing significant property damage and loss of life (e.g., Fujita and Wakimoto 1981; Johns and Hirt 1987; Przybylinski 1995; Jorgensen and Weckwerth 2003; Atkins et al. 2004). Observational studies indicated that the middle and lower reaches of Yangtze River are the active region of squall lines, and the maximum frequency of occurrence is in the northern part of Jiangsu Province (Ding 1993; Bei et al. 2002; Sun et al. 2010; Meng et al. 2013). Numerical simulations have been conducted to understand the role of the large-scale

Responsible Editor: E.-K. Jin.

Liguang $\mathrm{Wu}$

liguangwu@fudan.edu.cn

1 Pacific Typhoon Research Center (PTRC) and Key Laboratory of Meteorological Disaster of Ministry of Education, Nanjing University of Information Science and Technology, Nanjing, China

2 Department of Atmospheric and Oceanic Sciences and Institute of Atmospheric Sciences, Fudan University, Shanghai, China environment in the occurrence of squall lines, but little attention has been paid to the effects of mountains and lakes in the area.

The observational analysis shows that the squall line occurs in the middle and lower reaches of Yangtze River from March to October, with a peak in July (Meng et al. 2013). The diurnal variation shows a major peak in the early evening and two minor peaks in the early morning and early afternoon. In Meiyu season, there is a short or long trough in northern China to the north of $30^{\circ} \mathrm{N}$, while the northwest Pacific subtropical high is to its southeast (Sampe and Xie 2010). Moisture is transported through the southeasterly flow on the western flank of the subtropical high (Ding 1993; Meng et al. 2013). In addition to the westerly trough and subtropical high, the synoptic-scale circulation associated with the occurrence of squall lines in east China can also be associated with a cold vortex or tropical cyclone (Meng et al. 2013). It is found that the low-level jet plays a role in transporting water vapor and triggering convection, especially in Meiyu season (Xu et al. 2009). These studies highlight the importance of the large-scale atmospheric environment for the occurrence of squall lines.

Kodama and Barnes (1997) indicated that topography might cause persistent convergence in localized regions. Based on a 
series of the field campaigns, such as the Southwest Monsoon Experiment/Terrain-Influenced Monsoon Rainfall Experiment (SoWMEX/TiMREX; Davis and Lee 2012), the Mesoscale Alpine Programme (MAP; Rotunno and Houze 2007) and the MAP Demonstration of Probabilistic Hydrological and Atmospheric Simulation of Flood Events (MAP-DPHASE; Rotach et al. 2009) projects, and the Convective and Orographically Induced Precipitation Study (COPS; Wulfmeyer et al. 2011), it is suggested that an intense low-level, wet airflow impinging on mountains can induce the occurrence of squall lines by providing sufficient moisture and triggering convection (Buzzi and Foschini 2000; Nuissier et al. 2008; Ducrocq et al. 2008). Some other studies also suggest that mountains provide an effective mechanism for triggering convection and accumulating the unstable energy (e.g., Smith 1979; Buzzi and Foschini 2000; Bousquet and Smull 2003).

There are mountains with altitudes of more than $1000 \mathrm{~m}$ to the north of Jiangsu Province (Fig. 1a). Considering squall lines that affect north Jiangsu Province often start in this region, it is necessary to investigate the effect of the mountains on the formation of squall lines in northern Jiangsu Province. In addition, there are two relatively large lakes in northern Jiangsu Province (Fig. 1a). One is Hongze Lake, the fourth largest freshwater lake in China and the other is Gaoyou Lake, the sixth largest lake in China. Hongze Lake is centered at 33.5 ${ }^{\circ} \mathrm{N}, 118.5^{\circ} \mathrm{E}$, covering an area of $2069 \mathrm{~km}^{2}$. Gaoyou Lake is to the southeast of Hongze Lake, with an area of $760 \mathrm{~km}^{2}$. Although previous studies have been carried out on numerical simulations, convection was not well simulated, because of the coarse resolution (Yu and Chen 1984; Qian 1987). Lericos et al. (2007) discussed the effect of coastline on the evolution of squall lines by the two-dimensional idealized model. The wind shear profiles were given in their simulation, but the effect of water on vertical wind shear was not included. To our knowledge, few studies have focused on the influence of mountains and lakes on the occurrence of the squall line in northern Jiangsu Province.

To understand why the squall line often occurs in northern Jiangsu Province, we focus on the effects of the mountains and lakes in this study by simulating the squall line that was observed on 14 June 2009. The overview of the squall line is presented in Sect. 2 and the design of the numerical experiments is described in Sect. 3. In Sect. 4, the simulations of the squall line are verified with observational data, followed by the discussion of the effects of mountains and lakes in Sects. 5 and 6. A brief summary of this study is provided in Sect. 7.

\section{Overview of the 14 June 2009 squall line}

In this study, the observational data from the operational S-band Doppler radars in Nanjing are used to identify the evolution of the squall line (Fig. 1b), which is similar to
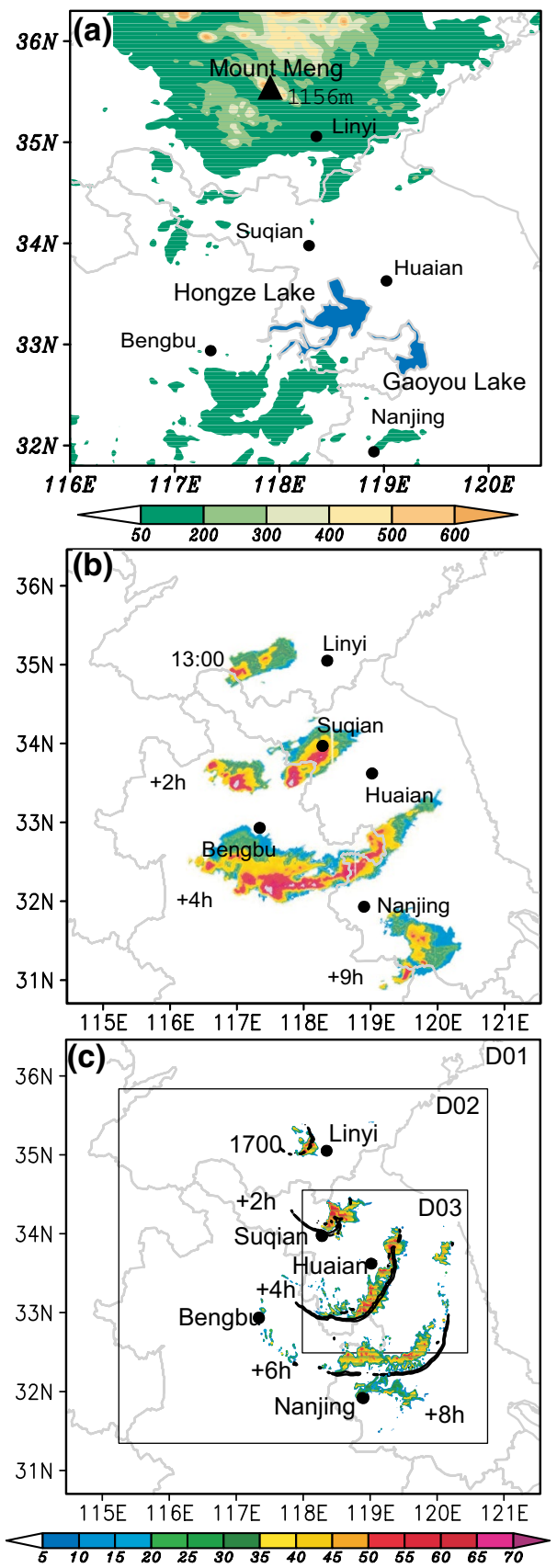

Fig. 1 a Terrain altitude (shading, $m$ ) in the region of the squall line activity with the blue shading indicating the lakes. b Observed radar reflectivity (shading, dBZ) at 1300, 1500, 1700, 2200 BST 14 June 2009. c Horizontal grids used for numerical simulations of quasi-linear convective systems on 14 June 2009. In each case, d01, $\mathrm{d} 02$, and $\mathrm{d} 03$ utilize $3-, 1-$, and $0.333-\mathrm{km}$ horizontal grid spacings, respectively. $3-\mathrm{km}$ radar reflectivity simulated in the control experiment. The contours of the updraft of $1 \mathrm{~m} \mathrm{~s}^{-1}$ at $1 \mathrm{~km}$ AGL indicate the approximate location of the gust front. The hours labeled with the system are relative to 1300 BST and 1700 BST 14 June 2009 in b and c, respectively. The black dots are the locations of related cities 
Weather Surveillance Radar-1988 Dopplers (WSR-88Ds) in the United States in terms of both their hardware and software. The station precipitation and wind observations are from the China Meteorological Administration (CMA). Moreover, the National Centers for Environmental Prediction (NCEP) FNL (Final) Operational Global Analysis data, which are updated every $6 \mathrm{~h}$ on $1.0 \times 1.0$ degree, are also used for the simulation and analysis in this study.

Radar observation indicates that the initial convection of the squall line was first found to the west of Linyi City around 1400 Beijing Standard Time (BST) on 14 June 2009 (Fig. 1b). Based on the FNL analysis, the formation of the squall line was associated with a short westerly trough at $500 \mathrm{hPa}$ in North China (Fig. 2a), one of the typical synoptic-scale patterns favorable for the development of squall lines (Meng et al. 2013), and a weak anticyclone at $850 \mathrm{hPa}$ over northern Jiangsu Province (Fig. 2b). The field of equivalent potential temperature $\left(\theta_{\mathrm{e}}\right)$ at $500 \mathrm{hPa}$ suggests that the northwesterly winds carried cold, dry air to about $30^{\circ} \mathrm{N}$, forming a relatively dense temperature contour (frontal) area on the border between Shandong and Jiangsu Provinces. In the pre-Meiyu season, the northwest Pacific subtropical high did not extend to the region. The calculated columnintegrated precipitable water shows a moderate band of $44 \mathrm{~kg} \mathrm{~m}^{-2}$ to the South of the front (Fig. 2a).

At the same time, the convective available potential energy (CAPE) accumulated in the northern part of Jiangsu Province (Fig. 2b). A typical thermodynamic sounding from the FNL analysis with vertical variations of the wind in the frontal area is shown in Fig. 3. The near-surface air was nearly saturated and the average CAPE in the region of convective initiation was more than $900 \mathrm{~J} \mathrm{~kg}^{-1}$, and even more than $2400 \mathrm{~J} \mathrm{~kg}^{-1}$ at some locations. The convective inhibition and lift indices were as low as $1 \mathrm{~J} \mathrm{~kg}^{-1}$ and -8 , respectively. Compared with the cases discussed in Meng et al. (2013), the thermodynamic condition was favorable for the occurrence of squall lines. In addition, the low-level vertical wind shear between 1000 and $600 \mathrm{hPa}$ was more than $10 \mathrm{~m} \mathrm{~s}^{-1}$. Previous studies indicated that the strong low-level vertical wind shear perpendicular to the convective line is favorable for the formation and development of the convective line (e.g Rotunno et al. 1988; Weisman et al. 1988; Keenan and Carbone 1992; Weisman 1993; Robe and Emanuel 2001; Weisman and Trapp 2003).

Over the next few hours, the convection cells along the front were organized into a squall line. The squall line then passed over Hongze Lake and Gaoyou Lake in northern Jiangsu Province (Fig. 1b). At 1730 BST, the squall line extended $200 \mathrm{~km}$ in length, with a distinct large bow echo, indicating that it reached the mature stage. The squall line then continued to move southeastward and began to decay at $2000 \mathrm{BST}$. It produced the accumulated precipitation of
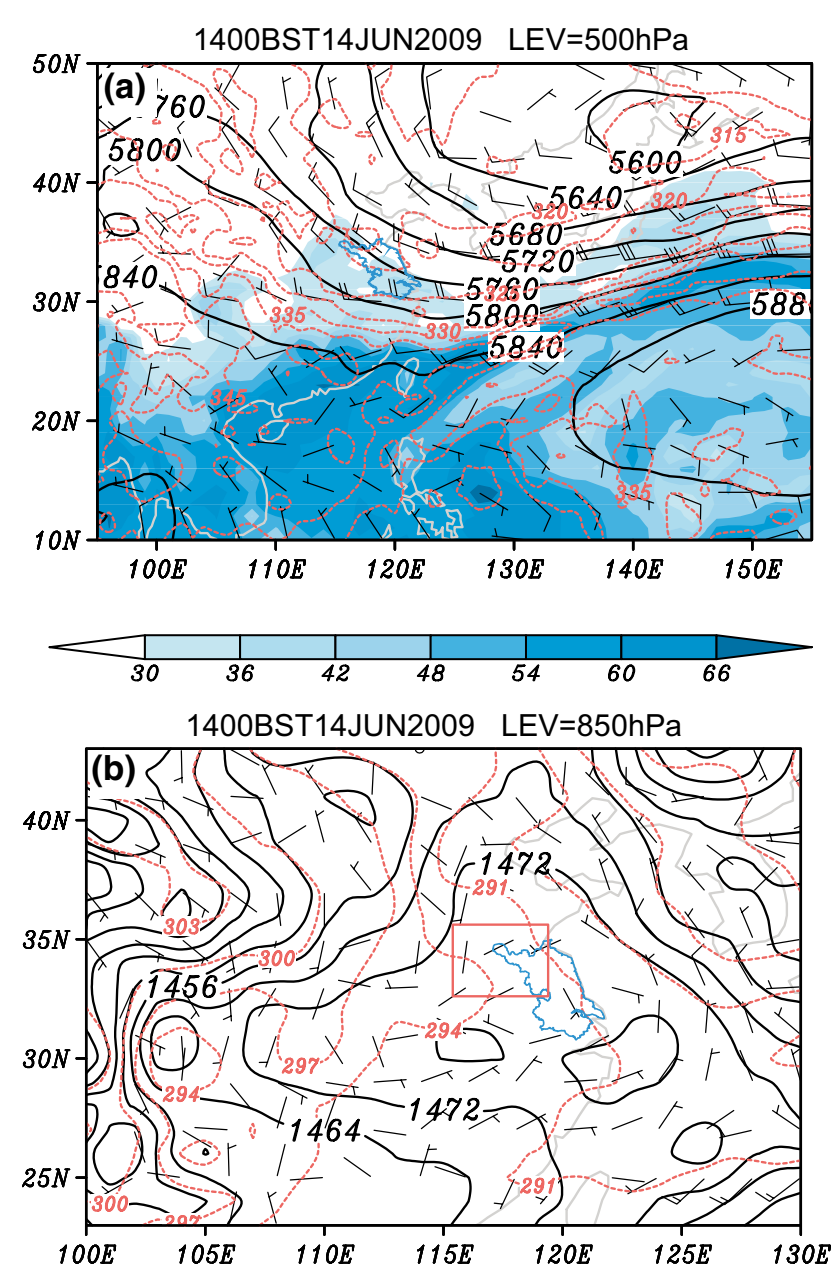

Fig. 2 a The fields of geopotential height (black contours, gpm), potential equivalent temperature (red contours, K), and winds (vectors) at $500 \mathrm{hPa}$, and column-integrated precipitable water greater than $24 \mathrm{~kg} / \mathrm{m}^{-2}$ (shading, $\mathrm{kg} \mathrm{m}^{-2}$ ) at 1400 BST 14 June 2009 from the FNL analysis. b The fields of geopotential height (black contours, $\mathrm{gpm}$ ), equivalent potential temperature (red contours, K), winds (vector) at $850 \mathrm{hPa}$, and CAPE (shaded, $\mathrm{J} \mathrm{kg}^{-1}$ ) from the FNL analysis. The closed blue line outlines the area of Jiangsu Province. The red box indicates the position of the average area in Fig. 3

more than $70 \mathrm{~mm}$. At some of the stations, the 2-min averaged wind speed exceeded $27 \mathrm{~m} \mathrm{~s}^{-1}$.

\section{Experimental design}

In this study, the multiscale processes leading to the development of the squall line on 14 June 2009 are simulated using a two-way triple-nested (3/1/0.333-km), Rotunn, cloud-resolving version of the Advanced Research Weather Research and Forecast model (WRF-ARW). The outermost domain covers an area of $600 \mathrm{~km} \times 600 \mathrm{~km}$ with a Lambert conformal map projection centered at $33.6^{\circ} \mathrm{N}, 118.00$ ${ }^{\circ} \mathrm{E}$. The size and location of each domain are shown in 


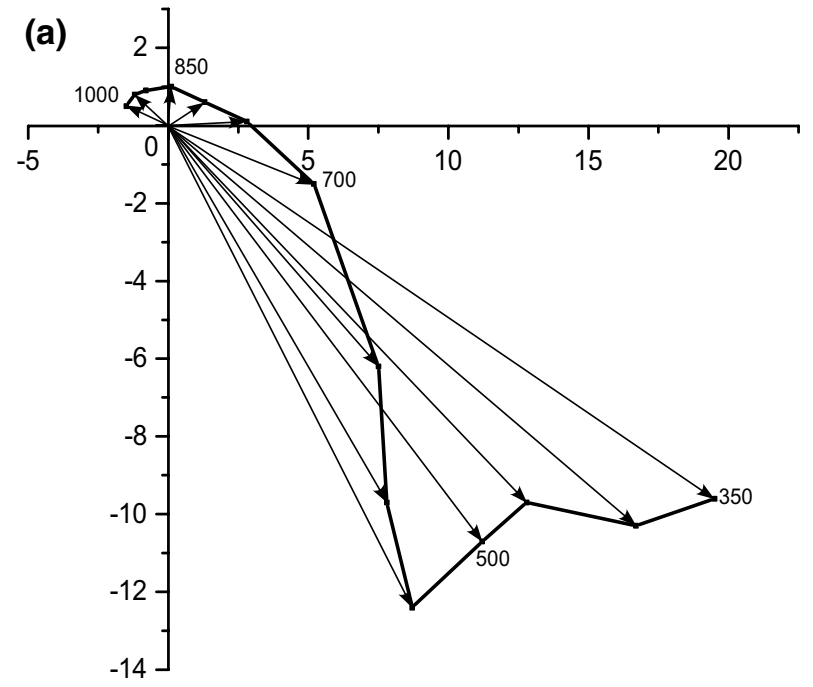

(b)

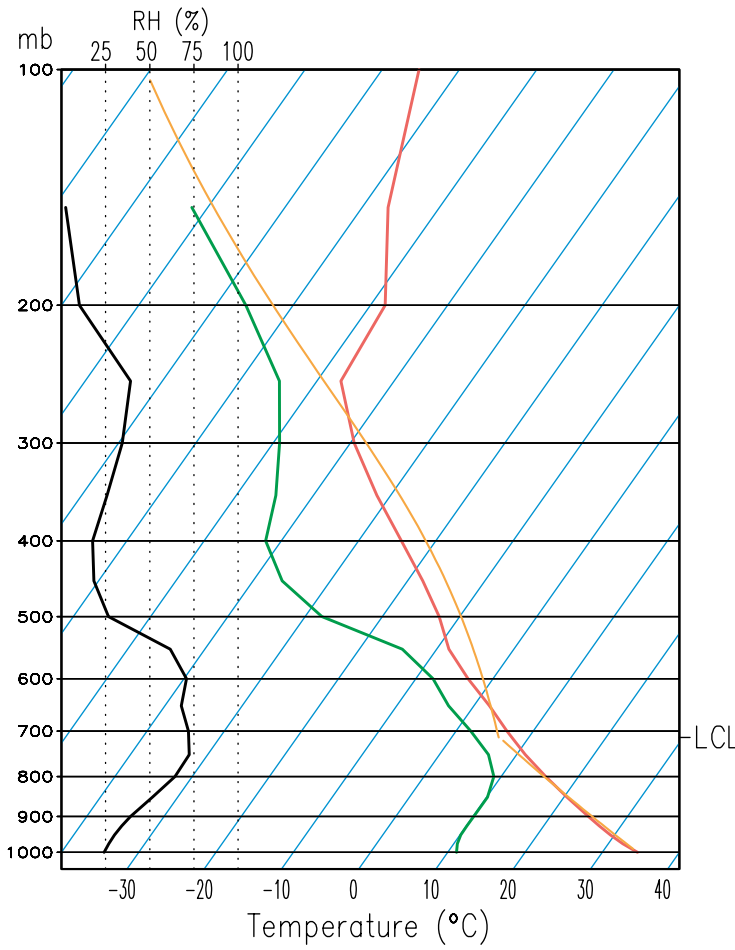

Fig. 3 a The hodograph of average winds (vector, $\mathrm{m} \mathrm{s}^{-1}$ ) between 1000 and $350 \mathrm{hPa}$ at $1400 \mathrm{BST} 14$ June 2009 from the FNL analysis, which are averaged over the orange box in Fig. 2b; b The sounding at 1400 BST 14 June 2009 from the FNL analysis, with the average area being shown in Fig. $2 b$

Fig. 1c, where Domain 2 and Domain 3 cover an area of $480 \mathrm{~km} \times 480 \mathrm{~km}, 220 \mathrm{~km} \times 220 \mathrm{~km}$, respectively. In the control experiment (EXP-C), all domains consist of 60 vertical levels. The terrain resolution is $30 \mathrm{~s}$. The model physics include the WSM6 microphysics scheme, YSU planetary boundary layer scheme, Dudhia shortwave radiation scheme, and Noah land surface scheme. The 3-km and 1-km domains start at 1000 BST (i.e., 0200UTC) 14 June 2009, 4 h before the occurrence of the observed convective cells on the border of Shandong and Jiangsu Provinces. The 0.333-km nested domain is activated $8 \mathrm{~h}$ later at $1800 \mathrm{BST}$, and then the experiment continues to integrate for $16 \mathrm{~h}$. The FNL (Final) Operational Global Analysis data are used for the model initial and lateral boundary conditions that are interpolated at 1-h intervals. The discussion of the accumulated precipitation and the evolution of the squall line are mainly based on the output of the $1-\mathrm{km}$ resolution domain, while the structure of the squall line at maturity stage (2130BST) is derived from the output of the $0.333-\mathrm{km}$ nested domain since the data in the $0.333-\mathrm{km}$ domain show finer structure of the squall line.

Three sensitivity experiments are designed to investigate the effects of the mountains in Linyi City and the lakes in northern Jiangsu Province. The sensitivity experiment (EXP-M) examines the impact of terrain to trigger the convection, in which all terrain above $100 \mathrm{~m}$ is set to $100 \mathrm{~m}$ and then, interpolate the meteorological variables in the vertical coordinates of the terrain. EXP-L1 and EXP-L2 are designed to examine the effect of the lakes. The lakes are replaced by soil in EXP-L1 and are doubled in area in EXP-L2, respectively. In EXP-L2, we keep the shape of the lakes and enlarge the area. First, we counted the number of grids of water in the EXP-C, and then expand to the outside along the lakes. We continuously counter the total number of grids in this process. When the number of grids of the new water body is twice that of the original one, the lake area is considered to have doubled.

\section{Verification of the control simulation}

The evolution of the simulated squall line is shown in Fig. 1c, in which the radar reflectivity at $3 \mathrm{~km}$ and the vertical motion of $1 \mathrm{~m} \mathrm{~s}^{-1}$ at $1 \mathrm{~km}$ are plotted over a 10-h period. Compared to the observation (Fig. 1b), the simulated convection is initiated in the mountainous area to the west of Linyi City around $1600 \mathrm{BST}, 4 \mathrm{~h}$ later than the observation. The convection is triggered about $50 \mathrm{~km}$ south of the mountains, which extend generally in the northwest-southeast direction (Fig. 1a). Close examination indicates that the initial convection includes two areas of the enhanced radar reflectivity at $7 \mathrm{~km}$ (Fig. 4a). The strong ascending motion coincides with the enhanced reflectivity, surrounded by the subsidence. The updraft over $12 \mathrm{~m} \mathrm{~s}^{-1}$ can be found at $7 \mathrm{~km}$ in the stronger cell. Note that the surface precipitation has not formed yet at this time.

By 1930 BST, the convective cells evolve into a multicell convective system between Suqian City and Huaian City. As shown by the shaded of the simulated 3-km reflectivity exceeding $30 \mathrm{dBZ}$ (Fig. 4b), the system is oriented in the northeast-southwest direction and extends about 

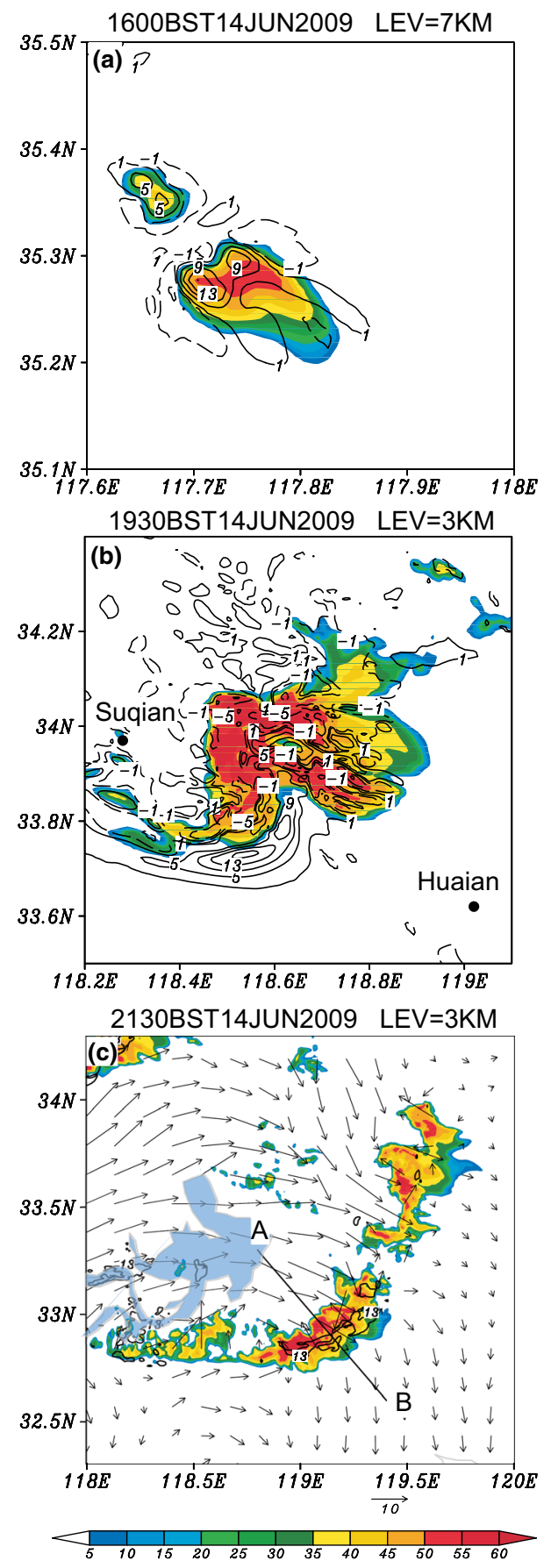

Fig. 4 a The 7-km simulated radar reflectivity (shading, dBZ) and vertical velocity (contours $\mathrm{m} \mathrm{s}^{-1}$ ) with solid and dash contours indicating upward and downward vertical motion at 1600 BST 14 Jun 2009 , respectively. b Same as a, but for 1930 BST at $3 \mathrm{~km}$. c The 3-km simulated radar reflectivity (shading, dBZ) and storm-relative flow (vectors) at 2130 BST with the black contours indicating the horizontal wind speed of $13 \mathrm{~m} \mathrm{~s}^{-1}$ at $10 \mathrm{~m}$. The line $\mathrm{AB}$ indicates the position of the vertical cross-section in Fig. 5. The Hongze Lake is highlighted by the blue shading
$100 \mathrm{~km}$, with strong upward motion on the southwest side of the leading edge. The alternating updrafts and downdrafts suggest that the mesoscale convective system consists of convective cells. The radar reflectivity indicates the formation of the bow echo at 1930 BST and the convective cells dissipate in the northern part due to the clockwise vertical wind shear (Fig. 3a). The system moves southeast like the observation and begins to influence the northern part of Jiangsu Province at 1930 BST.

Although the simulated convective cells start $3 \mathrm{~h}$ later than the observation, as shown in Fig. 4c, the squall line is well simulated in the control experiment. When the system passes through Hongze Lake and Gaoyou Lake to the southeast of Huaian City, it develops into a squall line approximately $300 \mathrm{~km}$ in length by $2130 \mathrm{BST}$, with nearmirror image cyclonic and anticyclonic book-end vortices at $3 \mathrm{~km}$ (Fig. 4c). Here, we use the contour of $1 \mathrm{~m} \mathrm{~s}^{-1}$ ascending motion at $1 \mathrm{~km}$ AGL to roughly indicate the position of the gust front. The simulated gust front can be clearly seen in Fig. 1c. The strong winds greater than $13 \mathrm{~m} \mathrm{~s}^{-1}$ at 2130 BST can be seen in Fig. 4c.

Figure 5a shows the streamlines of storm-relative flows along the line $(\mathrm{AB})$ perpendicular to the squall line. The upward motion more than $12 \mathrm{~m} \mathrm{~s}^{-1}$ coincides with the strong reflectivity exceeding $45 \mathrm{dBZ}$. The frontal inflow is in the boundary layer near the gust front, extending upward through the convective region. Because of the strong northwest flow in the middle and upper levels, the ascending front-to-rear flow is weak and the precipitation is mainly in the convective region in this case. This is consistent with the observed gale disasters. Meanwhile, the rear-inflow jet and precipitation lead to a cold pool of $-5 \mathrm{~K}$ near the surface (Fig. $5 \mathrm{~b}$ ).

Figure $5 \mathrm{~b}$ further shows the low-level cold pool and the pressure perturbations. Following Adams-Selin et al. (2013), the potential temperature perturbation is obtained by subtracting a constant of $300 \mathrm{~K}$. We only plotted the negative contours and there are no negative potential temperature perturbations in the middle or upper levels. The low-level cold pool is associated with positive pressure perturbations below $2 \mathrm{~km}$. As pointed out by previous studies (e.g. Lemone et al. 1984; Fovell and Ogura 1988), a significant negative pressure perturbation, about $10 \mathrm{~km}$ wide, is located below the primary sloping buoyant convective updraft. Farther to the rear, there is another area with negative pressure perturbations on a larger horizontal scale in the vicinity of the melting layer. Previous studies have suggested that the negative pressure here is associated with the positively buoyant air in the stratiform cloud above (Houze 1989). Although the stratiform cloud in our results is not well simulated, the reason for the negative pressure may also be this principle. In addition, there are positive pressure perturbations coinciding with the cold 

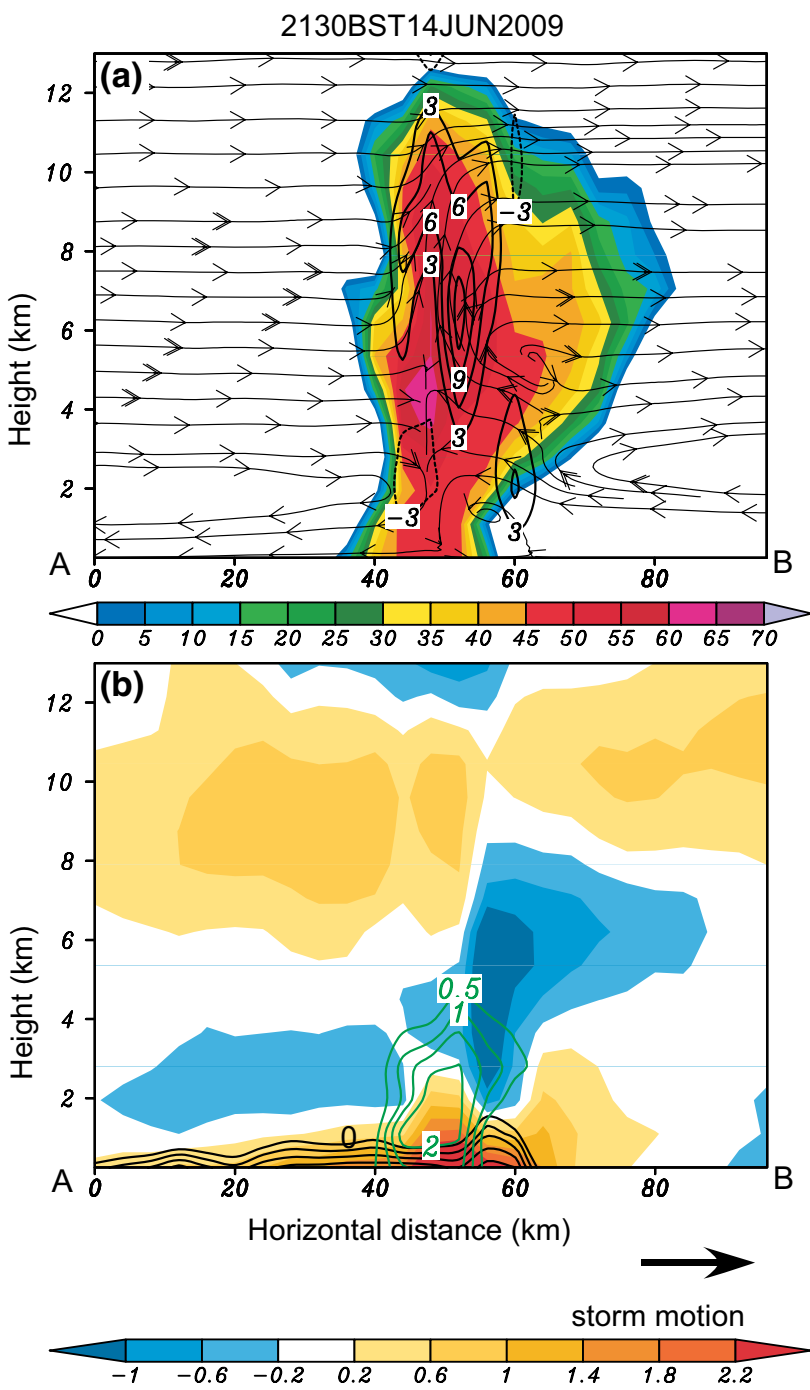

Fig. 5 a Vertical cross-section of radar reflectivity (shading, dBZ), storm-relative flow (streamlines) and vertical motion (contours, $\mathrm{m} \mathrm{s}^{-1}$ ) with solid and dash contours indicating upward and downward vertical motion, respectively; b vertical cross-section of the simulated pressure perturbation (shading, $\mathrm{hPa}$ ) and rain mixing ratio (green contours, $0.5 \mathrm{~g} \mathrm{~kg}^{-1}$ ). The cold pool potential temperature perturbation below $0 \mathrm{~K}$ is plotted at $1 \mathrm{~K}$ intervals (thick black contours). The cross-section is plotted along the line in Fig. 4

pool and positive pressure perturbations aloft extending over the trailing stratiform region.

Although the model-simulated bow echo occurs about 3-4 $\mathrm{h}$ later than the observed and the location is shifted about $100 \mathrm{~km}$ to the northwest, we can find that the model reasonably well simulates the evolution of the squall line and the extreme rainfall in the middle portion of the rainfall belt, especially the simulation of heavy precipitation areas (Fig. 6a, b). The structure of the simulated squall line is comparable to the general structure of the squall line
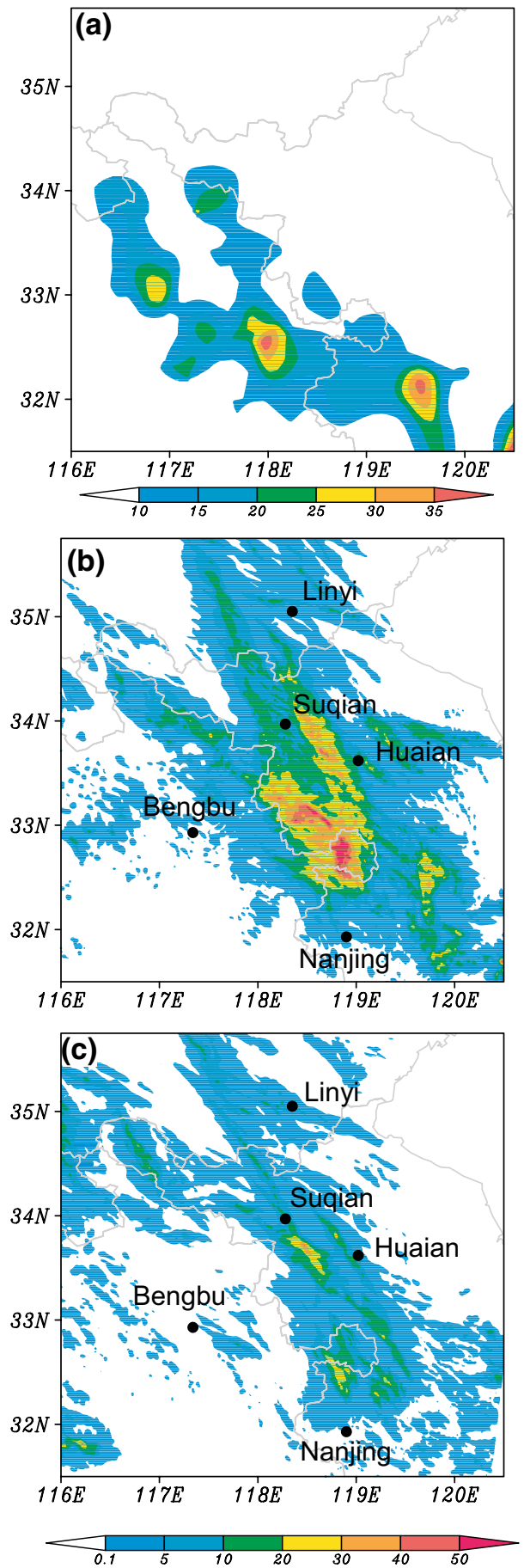

Fig. 6 The accumulate precipitation (shading, mm) from 1700 BST 14 June to 0200 BST 15 June in a observation, b EXP-C and $\mathbf{c}$ EXP$\mathrm{M}$, respectively. The black dots are the locations of related cities

revealed in previous studies. Note that the aforementioned biases are common in the simulation of real mesoscale convection systems (e.g., Wheatley and Trapp 2008; Davis and Galarneau 2009). 


\section{Effect of mountains}

As discussed in the last section, the convective cells are initiated to the northwest of Linyi City, where Mountain Meng is located with 14 peaks over $1000 \mathrm{~m}$ in an area of $1125 \mathrm{~km}^{2}$. Figure 7 shows the terrain in the region and the water vapor mixing ratio (QVAPOR) at $250 \mathrm{~m}$ at $1600 \mathrm{BST}$ 14 June 2009 . We can see that the relatively high mixing ratio is mainly located to the south of the mountain area. Figure 7 further shows the terrain height and the obvious radar reflectivity near Linyi City at 1300 BST 14 June 2009. The convective cell occurs in the south slop of the mountain with the terrain height of about $200 \mathrm{~m}$.

Figure 8a is the cross-section of streamlines, water vapor mixing ratio and vertical motion $1 \mathrm{~h}$ before the convection is triggered ( 1500 BST) in EXP-C. The layer below $2 \mathrm{~km}$ is dominated by the southerly flows. When the low-level moist flows impinge the mountains, strong updrafts extend up to the height of $3 \mathrm{~km}$. The low-level southerly flow and the middle-level northerly flow may be enhanced by the valley wind since the mountain air is nearly warmest at $\sim 1500$ BST. The valley wind strengthens the vertical shear at the low levels, which is important to the convection formation. In addition, the accumulation of water vapor about $50 \mathrm{~km}$ south of the mountain ridge may also contribute to convective instability by increasing the CAPE.

To examine the role of Mountain Meng, a sensitivity experiment (EXP-M) is designed, in which the terrain elevation more than $100 \mathrm{~m}$ is set to $100 \mathrm{~m}$ and other settings are the same as those in EXP-C. Compared to the control experiment (EXP-C), the relatively strong updraft shifts southward between $70-80 \mathrm{~km}$ (Fig. 8b), where the vertical

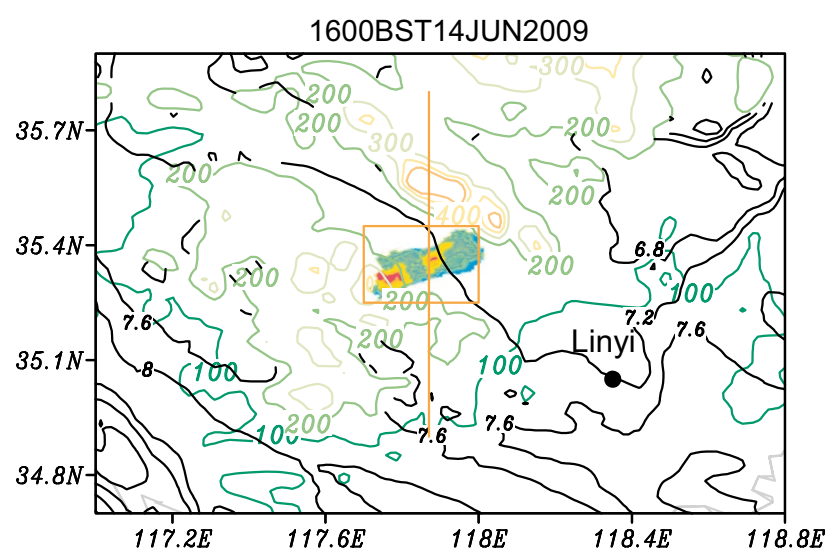

Fig. 7 The terrain height (colored contours, m) in the simulated domain, the water vapor mixing ratio (black contours, $\mathrm{g} \mathrm{kg}^{-1}$ ) at $250 \mathrm{~m}$, and observed radar reflectivity (shading, dBZ) at $1300 \mathrm{BST}$. The orange line and box indicate the position of the vertical cross in Fig. 8 and the average area in Fig. 9, respectively
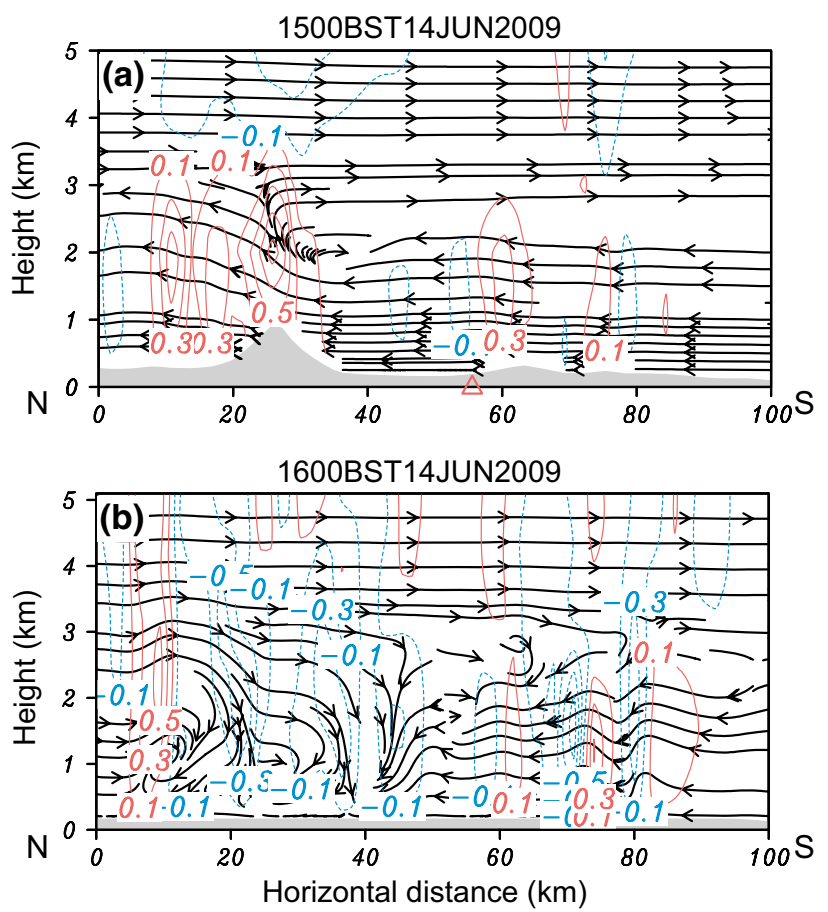

Fig. 8 a The vertical cross-section of the terrain height (shading, $\mathrm{m}$ ), water vapor mixing ratio (green contours, $\mathrm{g} \mathrm{kg}^{-1}$ ), wind (streamlines), and vertical velocity (contours). The red and blue contours indicate the upward and downward vertical motion $\left(\mathrm{m} \mathrm{s}^{-1}\right)$ at 1500 BST in EXP-C, respectively. b Same as a, but for 1600 BST in EXP-M. The cross-section is plotted along the line in Fig. 7

wind shear resulting from the low-level southerly flow and the middle-level northerly flow is clear. The valley wind is not clear and the convective cell forms about $3 \mathrm{~h}$ later than that in EXP-C. Lack of the mountain blocking leads to the warming of the air between 2 and $4 \mathrm{~km}$, but the water vapor at the low levels decreases by about $1 \mathrm{~g} \mathrm{~kg}^{-1}$. As a result, the convective instability has not been significantly weakened (Fig. 9a). On the other hand, the vertical wind shear at the low levels increases significantly due to the presence of Mountain Meng (Fig. 9b). At the beginning of the simulation, the difference of vertical wind shear is about $1 \mathrm{~m} \mathrm{~s}^{-1}$, but the difference increases gradually with time in EXP-C, reaching $8 \mathrm{~m} \mathrm{~s}^{-1}$ before the convective cell forms at $\sim 1500$ BST. The vertical shear in EXP-M is substantially weakened, less than $4 \mathrm{~m} \mathrm{~s}^{-1}$ after 1200 BST.

The strong low-level vertical shear is important for the formation and development of squall lines (e.g Rotunno et al. 1988; Weisman et al. 1988; Keenan and Carbone 1992; Weisman 1993; Robe and Emanuel 2001; Weisman and Trapp 2003). As shown in Fig. 10a, although the model also simulates the line-like convection that moves southeastward, it is much weaker than the squall line in EXPC. Figure 11a shows the simulated 7-km radar reflectivity and vertical motion at 1630 BST in EXP-M. Compared to 

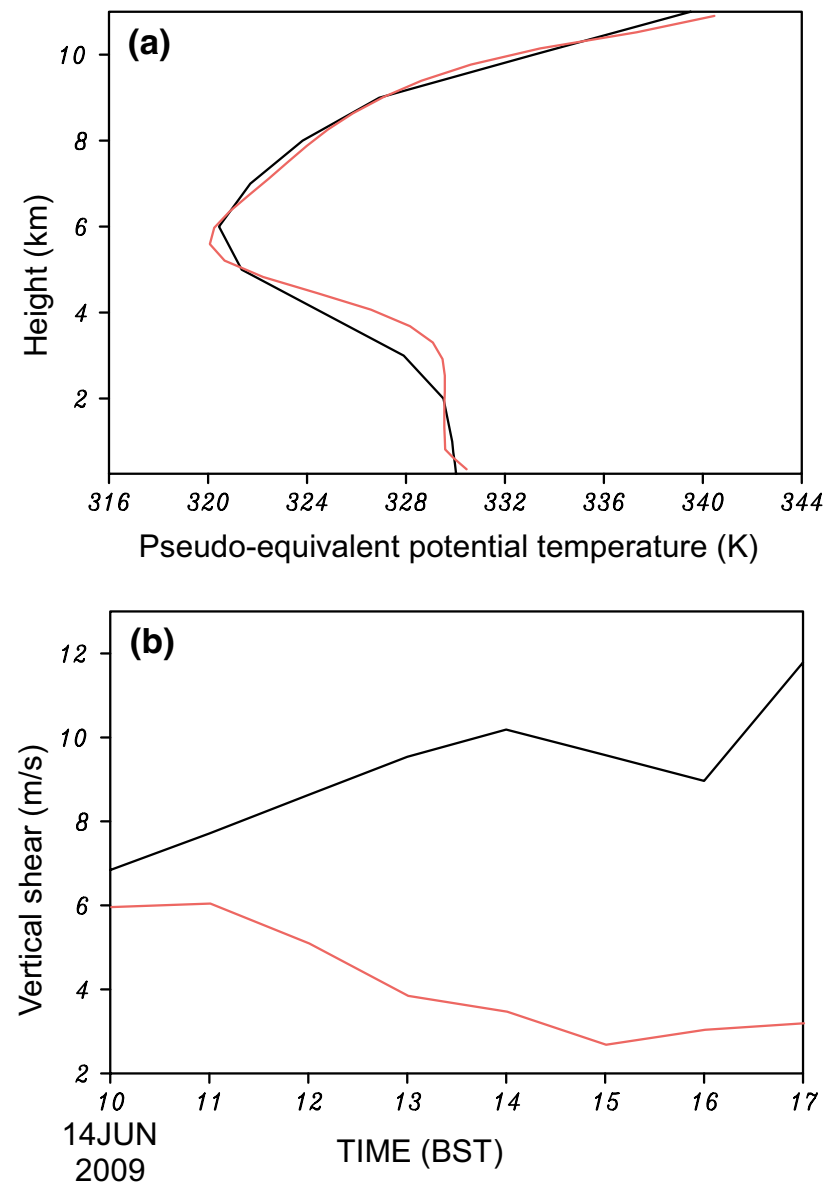

Fig. 9 a The vertical profile of potential pseudo-equivalent temperature in EXP-C at 1500 BST (black) and EXP-M at 1600 BST (red), respectively. $\mathbf{b}$ Time-dependent vertical wind shear between $0.25 \mathrm{~km}$ and $3 \mathrm{~km}$ in EXP-C (black) and EXP-M (red), respectively. The average area for the potential pseudo-equivalent temperature and vertical wind shear is shown in Fig. 7

Fig. 4a, the simulated convection is weaker in terms of the radar reflectivity and vertical motion. Although there are strong updrafts around $9 \mathrm{~m} \mathrm{~s}^{-1}$ at a height of $3 \mathrm{~km}$, an organized linear mesoscale convective system has not appeared by 2000 BST (Fig. 11b). We also examine the simulated precipitation in EXP-M and find that the precipitation area is smaller than the result of EXP-C (Fig. 6b, c).

We compare the temperature and meridional wind on the mountain and in the valley at the altitude of $1 \mathrm{~km}$ (Figure not shown). The temperature around the top of the mountain during $1500 \sim 1700 \mathrm{BST}$ is about $2{ }^{\circ} \mathrm{C}$ higher than that in the south valley at in EXP-C. The southerly wind is enhanced due to the thermal difference. When the mountain is removed in EXP-M, the temperature difference does not exist and northerly winds are enhanced. Therefore, we
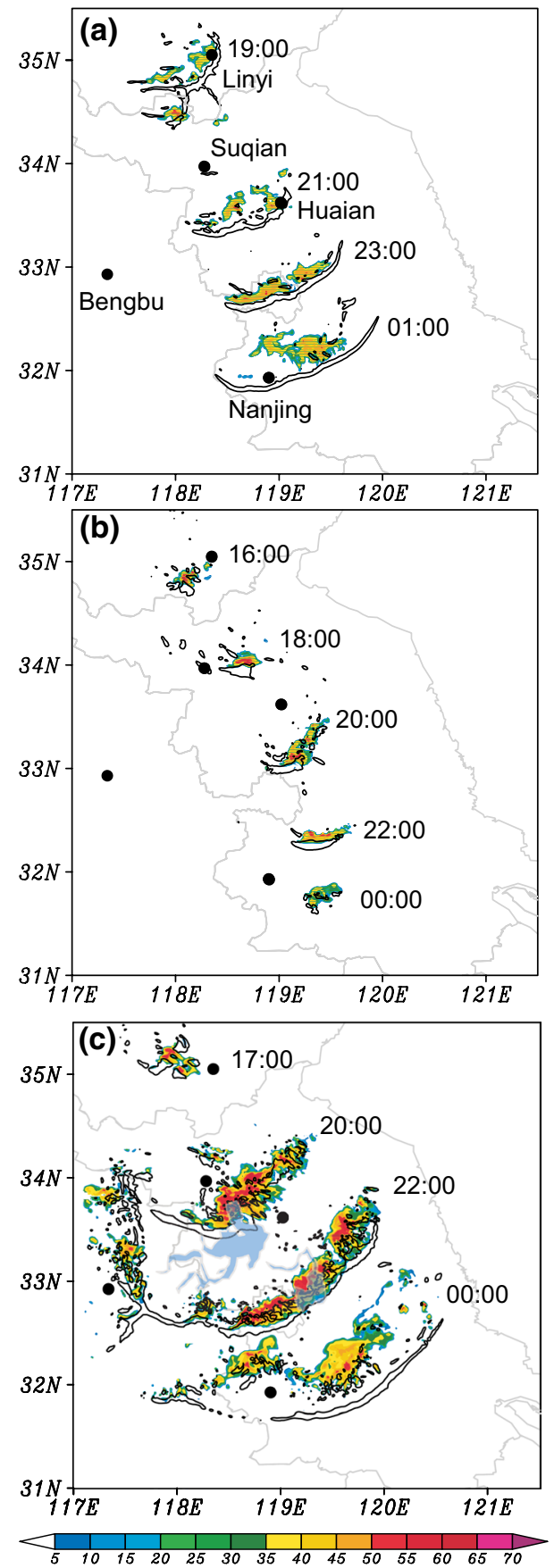

Fig. 10 a The radar reflectivity (shading, dBZ) simulated in EXP-M at $3 \mathrm{~km}$ with the updraft of $1 \mathrm{~m} \mathrm{~s}^{-1}$ (contours) at $1 \mathrm{~km} \mathrm{AGL.} \mathbf{b}$ and $\mathbf{c}$ are the same as a, but for the EXP-L1 and EXP-L2, respectively

conclude that the effect of the valley wind associated with Mountain Meng plays an important role in the early development of the squall line observed on 14 June 2009 by enhancing the vertical wind shear at the low levels. 


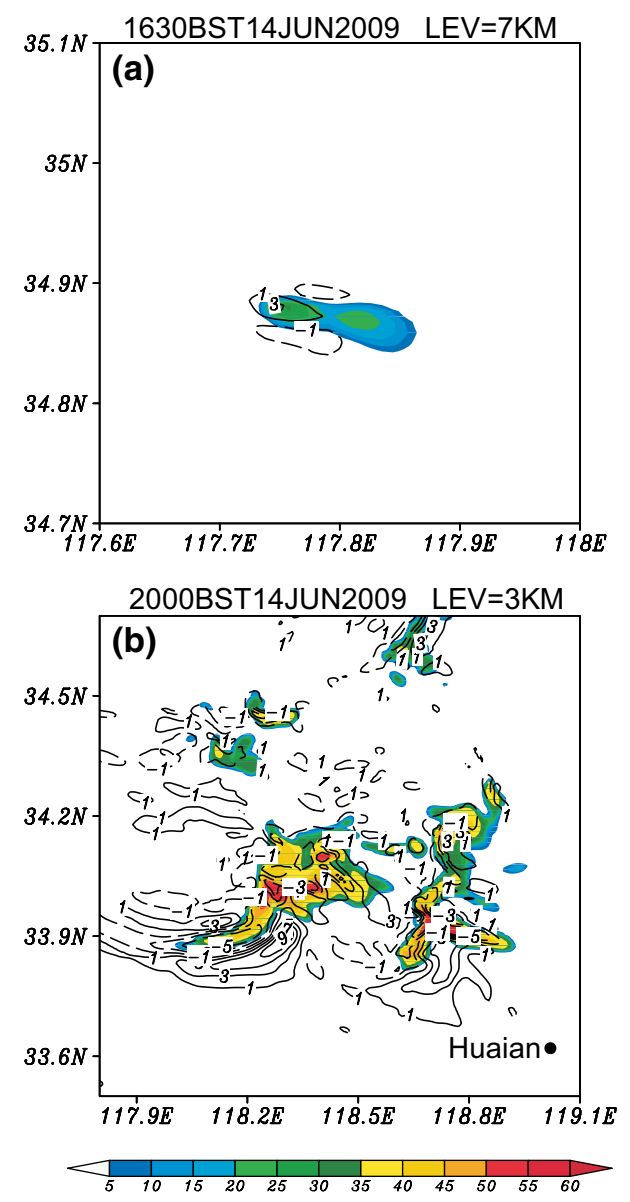

Fig. 11 a The simulated radar reflectivity (shading, dBZ) and vertical motion (contours) at $7 \mathrm{~km}$ with solid and dash contours indicating upward and downward vertical motion $\left(\mathrm{m} \mathrm{s}^{-1}\right)$ at 1630 BST 14 Jun 2009 in EXP-M, respectively. b The same as a, but for 2000 BST 14 Jun 2009 at $3 \mathrm{~km}$

\section{Lake effects}

As indicated in Figs. 4c and 5, the simulated squall line exhibits a typical mature structure after passing over the two lakes. It is suggested that the presence of Hongze Lake and Gaoyou Lake may promote the development of the squall line.

The effects of the lakes on the squall line are investigated using two sensitivity experiments, called EXP-L1 and EXP-L2. In EXP-L1, the lakes are replaced by soil, while in EXP-L2 the areas of the two lakes are doubled. As simulated in the control experiment (Fig. 1c), the convective cells in EXP-L1 also start to the west of Linyi at 1600 BST (Fig. 10b). As indicated in this figure, the convective cells are unable to develop into a squall line without the effects of the lakes. In contrast, the squall line simulated in EXP-L2 well develops with the doubled watery areas (Fig. 10c). It is strongly suggested that the lakes play an important role in the development of the squall line.
To understand the effect of the lakes, we compare the differences of the temperature and water vapor mixing ratio at $250 \mathrm{~m}$ between EXP-C and EXP-L1 before the squall line arrives at the lake region at 1700 BST (Fig. 12a). Compared to EXP-C, the water vapor mixing ratio in EXP-L1 is smaller, while the temperature is higher in the lake region at the low levels. Under the influence of the lakes, the temperature below $2 \mathrm{~km}$ decreases by about $2 \mathrm{~K}$. On the other hand, the water vapor mixing ratio increases by about $2 \mathrm{~g} \mathrm{~kg}^{-1}$ due to the presence of the water surface. As a result, the CAPE increases by $1000 \sim 1200 \mathrm{~J} \mathrm{~kg}^{-1}$ in the lake region (Fig. 12b). We conclude that the presence of the lakes leads to a more unstable environment for the development of the squall line.

As shown in Fig. 12a, the lake region is cold relative to the surrounding areas. In particular, the warm anomalies to the southeast of the lakes lead to a temperature gradient toward the southeast. The wind at the near surface is weak, while the wind is mainly dominated by the northwest flow at $3 \mathrm{~km}$ (Fig. 12a, b). Based on the thermal wind relationship, the horizontal temperature gradient enhances the vertical wind shear at the lower levels. To demonstrate this, we compare the vertical wind shear between the near surface and $3 \mathrm{~km}$ in EXP-C and EXP-L1. At the beginning of the experiments, the vertical wind shear is the same in EXP-C and EXP-L1, about $7 \mathrm{~m} \mathrm{~s}^{-1}$ (Fig. 12c). However, the vertical shear at low level in EXP-C increases to about $11 \mathrm{~m} \mathrm{~s}^{-1}$, while the vertical shear in EXP-L1 decreases to about $3 \mathrm{~m} \mathrm{~s}^{-1}$. The weaker low-level vertical shear is not conducive to the development of convection (e.g Rotunno et al. 1988). In addition to providing water vapor, the lakes promote the development of convection by enhancing the low-level vertical wind shear.

To further verify the results in EXP-L1, Fig. 10c shows the radar reflectivity and the contour of the updraft of $1 \mathrm{~m} \mathrm{~s}^{-1}$ in EXP-L2. In this experiment, the lake areas are doubled. In contrast to EXP-L1, the convection is significantly enhanced in EXP-L2, while the squall line passes through the lakes. The intensity of vertical motion and radar reflectivity are stronger than those from EXP-C. Consistent with the above discussion, the presence of the lakes in the northern part of Jiangsu Province promote the development of the squall line.

\section{Summary}

In this study, numerical experiments are conducted to focus on the effects of the mountains to the north of the plain of northern Jiangsu Province and the lakes that located in the central area of northern Jiangsu Province. The squall line selected in our simulations occurred on 14 June 2009.

The squall line occurred during the pre-Meiyu season under the influence of a short westerly trough at $500 \mathrm{hPa}$. 

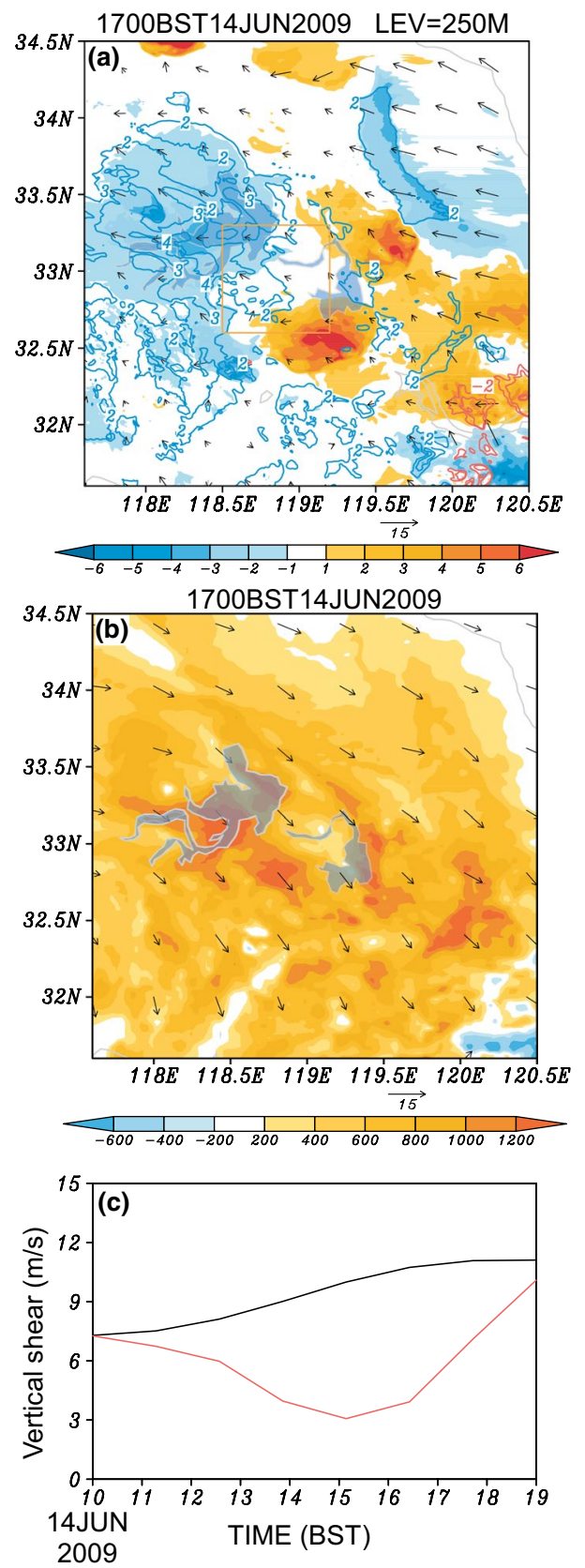

Fig. 12 a The difference of 250-m temperature (shading, K) and water vapor mixing ratio (contours, $\mathrm{g} \mathrm{kg}^{-1}$ ) between EXP-C and EXP-L1, and 250-m winds (vectors, $\mathrm{m} \mathrm{s}^{-1}$ ) in EXP-C at 1700 BST. b The difference of CAPE (contours, $\mathrm{J} \mathrm{kg}^{-1}$ ) between EXP-C and EXP$\mathrm{L} 1$ and winds (vectors, $\mathrm{m} \mathrm{s}^{-1}$ ) at $3 \mathrm{~km}$ in EXP-C at $1700 \mathrm{BST}$. Blue shading highlights Hongze Lake and Gaoyou Lake. $\mathbf{c}$ The time series of vertical wind shear between $0.25 \mathrm{~km}$ and $3 \mathrm{~km}$ in EXP-C (black line, $\mathrm{m} \mathrm{s}^{-1}$ ) and EXP-L1 (red line, $\mathrm{m} \mathrm{s}^{-1}$ ), respectively. The vertical wind shear is averaged over the orange box in a

The northerly transported the cold, dry air around $30^{\circ} \mathrm{N}$, meeting with the weak moist southerly northward flow at the low levels. The average CAPE in the region of convective initiation was more than $900 \mathrm{~J} \mathrm{~kg}^{-1}$ and the vertical wind shear between 1000 and $700 \mathrm{~h} \mathrm{~Pa}$ was $\sim 8 \mathrm{~m} \mathrm{~s}^{-1}$. Using the WRF model with the grid spacings of $3 \mathrm{~km}$, $1 \mathrm{~km}$, and $333 \mathrm{~m}$, the squall line is well simulated, although the model-simulated bow echo occurs about 3-4 h later than the observed and the location is shifted about $100 \mathrm{~km}$ to the northwest. The model reasonably well simulates the evolution of the squall line and the extreme rainfall in the middle portion of the rainfall belt. The structure of the simulated squall line is comparable to the general structure of the squall line revealed in previous studies.

A sensitivity experiment is conducted to examine the effects of Mountain Meng, in which the terrain elevation more than $100 \mathrm{~m}$ is set to $100 \mathrm{~m}$. The model fails to simulate the development of the squall line and an organized linear mesoscale convective system does not form by 2000 BST. Examination suggests that the presence of the mountain leads to the circulation of the valley wind to the south of the mountain in the afternoon. The effect of the valley wind associated with Mountain Meng plays an important role in the early development of the squall line observed on 14 June 2009 by enhancing the vertical wind shear at the low levels, which is important for the formation and development of squall lines (e.g Rotunno et al. 1988; Weisman et al. 1988; Keenan and Carbone 1992; Weisman 1993; Robe and Emanuel 2001; Weisman and Trapp 2003).

The effects of Hongze Lake and Gaoyou Lake are examined by conducting the two sensitivity experiments. The presence of the lakes leads to a relatively cold area in the region of the two lakes. The warm temperature anomalies to the southeast of the lakes result in a temperature gradient toward the southeast at the low levels. Due to the thermal wind relationship, the horizontal temperature gradient enhances the westerly vertical wind shear. The sensitivity experiment indicates that the absence of the lakes can significantly reduce the low-level vertical wind shear. In other words, the lakes promote the development of convection by enhancing the low-level vertical shear. It should be pointed out that we only investigated the squall line on June 14, 2009. Further research is needed to fully understand the frequent occurrence of squall lines in the plain of northern Jiangsu Province.

Acknowledgements This research was jointly supported by the National Basic Research Program of China (2015CB452803), the National Natural Science Foundation of China (41730961, 41675051, 41675009), and Jiangsu Provincial Natural Science Fund Project (BK20150910).

Open Access This article is licensed under a Creative Commons Attribution 4.0 International License, which permits use, sharing, adaptation, distribution and reproduction in any medium or format, as long as you give appropriate credit to the original author(s) and the source, provide a link to the Creative Commons licence, and indicate if changes were made. The images or other third party material in this article are 
included in the article's Creative Commons licence, unless indicated otherwise in a credit line to the material. If material is not included in the article's Creative Commons licence and your intended use is not permitted by statutory regulation or exceeds the permitted use, you will need to obtain permission directly from the copyright holder. To view a copy of this licence, visit http://creativecommons.org/licenses/by/4.0/.

\section{References}

Adams-Selin RD, van den Heever SC, Johnson RH (2013) Sensitivity of bow-echo simulation to microphysical parameterizations. Weather Forecast 28(5):1188-1209

Atkins NT, Arnott JM, Przybylinski RW, Wolf RA, Ketcham BD (2004) Vortex structure and evolution within bow echoes. Part I: single-doppler and damage analysis of the 29 June 1998 derecho. Mon Wea Rev 132:2224-2242

Bei NF, Zhao SX, Gao ST (2002) Numerical simulation of a heavy rainfall event in China during July 1998. Meteor Atmos Phys $80: 153-164$

Bousquet O, Smull BF (2003) Observations and impacts of upstream blocking during a widespread orographic precipitation event. Quart J Roy Meteor Soc 129:391-409

Buzzi A, Foschini L (2000) Mesoscale meteorological features associated with heavy precipitation in the southern Alpine region. Meteor Atmos Phys 72:131-146

Davis CA, Galarneau TJ Jr (2009) The vertical structure of mesoscale convective vortices. J Atmos Sci 66:686-704

Davis CA, Lee WC (2012) Mesoscale analysis of heavy rainfall episodes from SoWMEX/TiMREX. J Atmos Sci 69:521-537

Ding YH (1993) Study on the lasting heavy rainfalls over the YangtzeHuaihe River Basin in 1991 (in Chinese). Chinese Meteorological Press, Beijing, p 255

Ducrocq V, Nuissier O, Ricard D et al (2008) A numerical study of three catastrophic precipitating events over southern France. II: mesoscale triggering and stationarity factors. Quart J Roy Meteor Soc 134:131-145

Fovell RG, Ogura Y (1988) Numerical simulation of a midlatitude squall line in two dimensions. J Atmos Sci 45:3846-3879

Fujita TT, Wakimoto RM (1981) Five scales of airflow associated with a series of downbursts of 16 July 1980 . Mon Wea Rev 109:1438-1456

Houze RA (1989) Observed structure of mesoscale convective systems and implications for large-scale heating. Q J R Meteorol Soc 115:425-461

Johns RH, Hirt WD (1987) Derechos: widespread convectively induced wind-storms. Wea Forecasting 2:32-49

Jorgensen DP, Weckwerth TM (2003) Forcing and organization of convective systems. Radar and atmospheric science: a collection of essays in honor of David Atlas. Amer Meteor Soc, Boston, pp $75-113$

Keenan TD, Carbone RE (1992) A preliminary morphology of precipitation systems in tropical northern Australia. Quart J Roy Meteor Soc 118:283-326

Kodama K, Barnes GM (1997) Heavy rain events over the southfacing slopes of Hawaii: attendant conditions. Weather Forecast 12:347-367

LeMone MA, Barnes GM, Zipser EJ (1984) Momentum flux by lines of cumulonimbus over the tropical oceans. J Atmos Sci 41:1914-1932
Lericos TP, Fuelberg HE, Weisman ML et al (2007) Numerical simulations of the effects of coastlines on the evolution of strong, longlived squall lines. Mon Wea Rev 135:1710-1731

Meng Z, Yan D, Zhang Y (2013) General features of squall lines in east China. Mon Wea Rev 141:1629-1647

Nuissier O, Ducrocq V, Ricard D et al (2008) A numerical study of three catastrophic precipitating events over southern France. I: numerical framework and synoptic ingredients. Quart J Roy Meteor Soc 134:111-130

Przybylinski RW (1995) The bow echo: observations, numerical simulations, and severe weather detection methods. Wea Forecasting 10:203-218

Qian W (1987) A numerical simulation study of the effect of the coldlake on the squall lines in the north part of Jiangsu province during summer. Scientia Meteorologica Sinca 2:56-65

Robe F, Emanuel KA (2001) The effect of vertical wind shear on radiative-convective equilibrium states. J Atmos Sci 58:1427-1445

Rotach MW, Ambrosetti P, Ament F et al (2009) MAP D-PHASE: real-time demonstration of weather forecast quality in the Alpine region. Bull Amer Meteor Soc 90:1321-1336

Rotunno R, Houze RA (2007) Lessons on orographic precipitation from the Mesoscale Alpine Programme. Quart J Roy Meteor Soc 133:811-830

Rotunno R, Klemp JB, Weisman ML (1988) A theory for strong, longlived squall lines. J Atmos Sci 45:463-485

Sampe T, Xie SP (2010) Large-scale dynamics of the Meiyu-Baiu rainband: environmental Forcing by the westerly jet. J Clim 23:113

Smith RB (1979) The influence of mountains on the atmosphere. Advances in Geophysics. Elsevier, Newyork, pp 87-230

Sun J, Zhao SX, Xu GK, Meng QT (2010) Study on a mesoscale convective vortex causing heavy rainfall during the meiyu season in 2003. Adv Atmos Sci 27:1193-1209

Weisman ML (1993) The genesis of severe, long-lived bow echoes. J Atmos Sci 50:645-670

Weisman ML, Trapp RJ (2003) Low-level meso-vortices within squall lines and bow echoes. Part I: overview and dependence on environmental shear. Mon Wea Rev 131:2779-2803

Weisman ML, Klemp JB, Rotunno R (1988) Structure and evolution of numerically simulated squall lines. J Atmos Sci 45:1990-2013

Wheatley DM, Trapp RJ (2008) The effect of mesoscale heterogeneity on the genesis and structure of mesovortices within quasi-linear convective systems. Mon Wea Rev 136:4220-4241

Wulfmeyer V, Behrendt A, Kottmeier C et al (2011) The Convective and Orographically-induced Precipitation Study (COPS): the scientific strategy, the field phase, and research highlights. Q J Roy Meteor Soc 137:3-30

Xu WX, Zipser EJ, Liu C (2009) Rainfall characteristics and convective properties of MeiYu precipitation systems over South China, Taiwan, and the South China Sea. Part I: TRMM observations. Mon Wea Rev 137:4261-4275

Yu Z, Chen L (1984) The influence of horizontally non-uniform heating upon the development of strong convective meso-scale disturbances. Chinese J Atmos Sci 8:36-45

Publisher's Note Springer Nature remains neutral with regard to jurisdictional claims in published maps and institutional affiliations. 